\title{
Værdiformsanalytisk rekonstruktion af Kapitalen. Del 3.
}

\author{
Michael Eldred, Marnie Hanlon, \\ Lucia Kleiber og Mike Roth.
}

\section{Introduktion.}

Vores fremstilling er nu nået så vidt, at en komplet rekonstruktion af Kapitalens bind 1 er tilendebragt. De læsere, som støder til her for første gang er naturligvis velkomne, men gøres opmærksom på, at ikke meget kan forstås, når det begrebslige grundlag, som er udviklet vha. den dialogdialektiske procedure mangler.

Dialektisk tænkning - eller værre, spekulativ tænkning er sunket så dybt i den kultiverede bevidsthed, at den udlægges som kunsten at forfægte, at sort er hvid eller som vildt, højtravende og derfor grundløst tankespind. Nutidens samfundsforskere vil i dag ikke være i stand til at gøre meget andet end at vedkende sig den moderne, dannede bevidstheds ureflekterede fordomme. Hvis Hegel på Marx' tid blev behandlet som en »død hund «, kunne han i dag være manden i månen, så lidt forbindelse har han med noget »nede på jorden«.

Samfundsforskeren søger i dag mere end nogensinde at plante sin fod solidt i empiriske og historiske »facts«. Dialektisk tænkning ville vise forskeren, at han/hun i realiteten står i kviksand. Men med presset fra en karrieremulighed i den akademiske verden har samfundsforskeren næppe nogen mulighed for at opdage, at der ikke er fast grund under fødderne. At stå i kviksand til op over ørerne har dog også sine behagelige og narkotiske sider. En omhyggelig vurdering af den dialektiske tænkning ville kræve mange rolige og uforstyrrede timers reflektion; noget som sjældent kan opfyldes under moderne arbejdsbetingelser indenfor og udenfor den akademiske verden.

Denne tredie del af vores serie omhandler to emner, som Marx diskuterer i Kapitalens 3. bind. I vores fremstilling begrunder vi, hvorfor vi har ændret den fremstillingssystematik, som Marx anvender i Kapitalen. Ligeledes gives der i tillæggene til de enkelte paragraffer omfattende kommentarer til Marx' behandling af de to emner, som begge optræder efter præsentationen af »loven om profitratens tendens til fald « i Kapitalens 3. bind. 
I den marxistiske tradition er denne lov ofte blevet betragtet som den egentlige afslutning af Kapitalen. I følge denne fortolkning er Marx' hovedværk en $\varnothing$ konomisk teori om kapitalismens bevægelseslove og krise.

Den formanalytiske kritik, som præsenteres i denne artikelserie, skulle gøre det klart, at sådanne »love« er humbug (se især VRAK 4 § $57 \mathrm{ff}$ ). Den betydning vi tillægger rente- og revenueformsanalysen (især sidstnævnte har ikke været genstand for megen opmærksomhed i sekundærlitteraturen, mens førstnævnte er blevet behandlet som en del af teorien om konjunkturcyklen og kreditsystemet) peger på en alternativ fortolkning af kritikken af den politiske økonomi som en formanalytisk kritik af фkonomiske kategorier og, herigennem, kritik af umiddelbar bevidsthed.

Renteformen er den mest feticherede fremtrædelsesform for det tingsliggjorte samfundsmæssige arbejdes (kapitalens) dominans over arbejdet. Rentebærende kapital er den endegyldige adskillelse af kapitalen fra arbejdet og dermed også pengekapitalistens løsgørelse fra den økonomiske aktivitet. Som det vil fremgå senere af den systematiske fremstilling efter kapitalanalysen indtager den rene rentier en særlig stilling hævet over den bestandige skiften mellem det private og konkurrencesatte livs sfærer. Rentieren demonstrerer på eksemplarisk vis indkomstformens centrale betydning for konstitueringen af den private sfære. Revenueformsanalysen præsenterer en fremtrædelsesform for forskellige værdikategorier, som mystificerer kapitalrelationen ved at udtrykke en symmetri og lighed mellem 3 karaktermasker overfor den aktive kapitalist (driftsherren). Den bevidsthed, som forbliver fanget af revenueformen kan heller ikke dechifrere den abstrakte lighed mellem ejendomsbesiddere, der fremtræder som et resultat af revenueformen. Begge emner for denne tredie del er derfor på ingen måde udtømt med kapitalanalysen.

Vi forfølger spørgsmålet om, eller i hvilken udstrækning, revenueformsanalysen kan betragtes som en analyse af den kapitalistiske $\varnothing$ konomis »overflade«. I denne forbindelse formulerer vi en fundamental kritik af Marx' »trinitariske formel « (§ 32). Denne kritik implicerer nødvendigheden af at tage klasse-begrebet op til fornyet overvejelse $(\S 33)$ på en måde som er fremmed for den konventionelle forståelse af »klasseanalyse«. Sædvanligvis er klasseanalyse en slags sociologisk eller historisk analyse, hvor empirisk identificerbare klasser dukker op i analysen af politiske begivenheder. Formanalysen overlader sådanne problemer til sociologer og historikere; den spekulative tænknings arbejde er afsluttet, når det modsigelsesfyldte $\mathrm{i}$ den nuvarende livsform er blotlagt for den umiddelbare bevidsthed.

Hverken sociologi eller historie, som begge mangler et modsigelsesbegreb, er i stand til at gøre dette. 
Endelig gives der i et appendix nogle kommentarer til noget af sekundærlitteraturen om revenueformsanalysen.

\section{Værdiens renteform.}

\section{$\S 24$}

Analysen af værdiens renteform begynder med at fokusere på den umiddelbare bevidsthed, at rentebærende penge er en bevægelse fra penge til flere penge, P - P'. Samtidig afsluttes analysen af den kapitalistiske produktionsproces med bestemmelsen af kapital som valoriserende værdi og således som en bevægelse fra penge til flere penge ( $§ 23$ ). Analysen af renten overskrider den umiddelbare bevidsthed gennem at etablere forbindelsen mellem penges evne til at oppebære rente og valoriseringen af kapital. I fremstillingen af kapital som en valoriseringsbevægelse, der formidles gennem produktionsprocessen, forblev det et åbent spørgsmål, hvor de penge, som blev udlagt som kapital, kommer fra. Den udlagte kapital begribes nu som udlånte penge. Rente er udlånsprisen på den udlagte kapital.

(a) Også Marx fokuserer på samtidens umiddelbare bevidsthed og sætter denne bevidsthed i forhold til et bestemt trin i den kategoriale udvikling:

».. varecirkulationen er udgangspunktet for kapitalen. ... Hvis vi ser bort fra det stoflige indhold i varecirkulationen, fra udvekslingen af forskelligartede brugsværdier, og kun betragter de økonomiske former, som denne proces afføder, så finder vi som dens sidste produkt pengene. Dette sidste produkt af varecirkulationen er den første form, hvori kapitalen fremtræder. ... Man behøver ... ikke noget tilbageblik på kapitalens tilblivelseshistorie for at erkende, at pengene er dens første fremtrædelsesform. Den samme historie udspilles dagligt for $\varnothing j n e n e$ af os. Enhver ny kapital træder stadigvæk i første omgang ind på scenen, dvs. markedet, varemarkedet, arbejdsmarkedet eller pengemarkedet, som penge, penge, der gennem bestemte processer skal forvandles til kapital« (Rh. 1,258, $\mathrm{K} 1,161)$.

Med ordene »varemarkedet, arbejdsmarkedet, eller pengemarkedet « sammenstiller Marx indledningsvist den produktive kapital ( $k \varnothing b$ af produktionsmidler på varemarkedet og leje af arbejdskraft på arbejdsmarkedet) med rentebærende pengekapital (lån af penge på pengemarkedet). Han refererer imidlertid på et efterfølgende trin til cirkulationsformen P - V - P og udelukker derved rentebærende kapital. Afsnittet konkluderer:

» $\varnothing$ be for at sælge, eller mere fuldstændigt, købe for at sælge dyrere, P - V - P', synes ganske vist kun at være betegnende for en enkelt art kapital, købmandskapitalen. Men også den industrielle kapital er penge, der forvandles til varer og gennem salget af varer atter forvandles til flere penge. ... 
Endelig, når det drejer sig om rentebærende kapital, fremtræder cirkulationen $\mathrm{P}-\mathrm{V}$ - P' i afkortet form, ... så at sige i lapidarstil, som P - P'.« (Rh. 1, 267f; K1 170)

Hvis vi her ser bort fra handelskapitalen (som vil blive behandlet i VRAK 4), så bemærkes det, at formlen P - P' for rentebærende kapital ikke kan formuleres som »købe for at sælge dyrere«. Men Marx opstiller en »kapitalens almene formel« (ibid), der dækker såvel kapital, der handler med varer (og penge?) som rentebærende kapital. Efterfølgende, i løbet af undersøgelsens af »modsigelserne i den almene formel«, begrænser han dog analysen til »kapitalens grundform « (Rh. 1, 278, K1 178): »I løbet af vor unders $\emptyset$ gelse vil vi finde, at både handelskapital og rentebærende kapital er afledede former for kapital« (Rh. 1, 280; K1, 179). I vores fremstilling behandler vi også først kun kapitalens grundform og udvikler så den rentebærende kapital som en afledet form.

(b) Marx fremhæver i begyndelsen af analysen af den rentebærende kapital i 3 . bind af Kapitalen, at rentebærende pengekapital skifter hænder på en karakteristisk måde, som må adskilles fra køb:

»... den særlige måde, hvorpå den sælges som vare, nemlig udlånes i stedet for at blive afstået en gang for alle. ... overladelse på betingelse af tilbagebetaling, er overhovedet långivningens og låntagningens bevægelse, denne specifikke form for kun betinget afhændelse af penge eller varer ... I stedet for at købe eller sælge låner han ud. Denne långivning er altså den behørige form, når man vil afhænde værdisummen som kapital i stedet for som penge eller som varer ... Långivning og låntagning, i stedet for salg og $\mathrm{k} ø \mathrm{~b}$, er her en forskel, som udspringer af varens - kapitalens - specifikke natur« (Rh. 3, 444f, 454, 457, 460; K3, 352, 360, 362 , 366).

Skønt Marx bemærker, at »penge, som udlånes på denne måde, i denne henseende har en vis analogi til arbejdskraft« (ved at begge midlertidigt stilles til kapitalistens rådighed EHKR), så drager han ikke eksplicit den konklusion, som vi har gjort i VRAK 2 § 11, nemlig at transaktionen mellem arbejder og kapitalist også er en lånerelation. At han ikke drager denne konklusion kan forklares med den afgørende betydning, som kategorien 'arbejdskraftens værdi' har i hans analyse, som kræver, at arbejdskraft behandles analogt med industrielle varer. I Teorier om mervardien - i særdeleshed i diskussionen med de, som befordrede opløsningen af den Ricardianske skole ved en tankeløs brug af udtrykket 'arbejdets pris' - understreger Marx ikke desto mindre den særegne egenskab ved transaktionen mellem arbejder og kapitalist, uden at han dog foretager adskillelsen mellem lånerelation og salgsrelation.

»Det som bringes til market er rigtig nok ikke arbejde men arbejderen. Det, som arbejderen sælger til kapitalisten er ikke hans arbejde, men den midlertidige brug af ham selv som arbejdskraft« (T 3, 132; TüM 3, 109). 
Den almindelige anvendelse af udtrykket »midlertidig brug « svarer til 'lån' eller 'leje' i samme betydning, som pengekapital er udlånt.

\section{$\S 25$}

Valoriseringen af penge som kapital, som blev udviklet i slutningen af VRAK 2 (\$ 23) kan nu mere præcist opfattes som brutto valorisering. Med introduktionen af rente opdeles kapitalens bruttovalorisering på netto valorisering og på renteafkast. I den rentebærende kapitals bevægelse står renten i forhold til den udlånte pengesum. Denne pengesum (hovedstolen) er imidlertid samtidig udlagt kapital og således udgangspunkt for valoriseringsbevægelsen. Kapitalens profit fratrukket renteudgiften for denne kapital kaldes nettoprofit eller virksomhedsprofit.

Man kan tale om en nettoprofitrate eller kapitalens nettovaloriseringsrate som analog til rentefoden.

I Marx' udkast til Kapitalens tredje bind kommer analysen af rentebærende kapital først efter en yderligere udvikling af profitbegrebet. Profit relateres først til industriel kapital og bestemmes kvantitativt som »gennemsnitsprofit «. Da denne udvikling bringer konkurrence ind i analysen, udskydes den i vores rekonstruktion til konkurrence-analysen. Ydermere udvides profitbegrebet i Marx' udkast ved, at analysen af »handelsprofit « placeres før undersøgelsen af rente. I begyndelsen af afsnittet om rente står der:

»Da vi først behandlede den almindelige eller gennemsnitlige profitrate (i denne bogs afsnit II) havde vi endnu ikke at gøre med denne sidste profitrate i den færdige form, idet udligningen endnu kun fremkom som udligning mellem de industrielle kapitaler, der var investeret i forskellige sfærer. Det blev kompletteret i det forudgående afsnit, hvor handelskapitalens deltagelse i denne udligning og den merkantile profit blev undersøgt. Den almindelige profitrate og gennemsnitsprofitten kom nu til at ligge inden for snævrere grænser end før. Under den videre redegørelse må det erindres, at når vi i det følgende taler om almindelig profitrate eller gennemsnitsprofit, sker det i den sidste betydning, altså kun med henblik på gennemsnitsprofittens færdige form. Da denne herefter er den samme for den industrielle og den merkantile kapital, er det heller ikke længere nødvendigt at skelne mellem industriel og kommerciel profit. Hvad enten kapitalen er investeret industrielt i produktionssfæren eller merkantilt i cirkulationssfæren, afkaster den i forhold til sin størrelse den samme årlige gennemsnitsprofit.«(Rh. 3 442, K3 350)

Efter denne indledning følger en meget sammentrængt bestemmelse af rente som en »del af profitten« (Rh. 3 443; K3 351ff).

Det forekommer os, at form-analysen i Marx' fremstilling, endnu engang sammenblandes med kvantitative bestemmelser og vi har besluttet at adskille disse to aspekter. De kvantitative bestemmelser vil først blive inddraget i kon- 
kurrence-analysen. Også Marx inddrager aspekter af konkurrence i behandlingen af gennemsnitsprofit og rentefoden, hvor »konkurrencen som sådan afgør« den sidstnævnte, og »afgørelsen (er) i og for sig tilfældig, rent empirisk, « (Rh. 3 472; K3 375). Analysen af renteformen forudsætter kun udviklingen af et kvalitativt begreb om profit ( $\$ 23$ ).

Den detaljerede udvikling af kapitalens bevægelse over tid, sådan som Marx udfører den i analysen af kapitalens cirkulation (i Kapitalens andet bind), og den efterfølgende analyse af handelskapitalen er ikke i systematisk fremstillingsmæssig henseende nødvendig for analysen af renteformen. I vores rekonstruktion har vi samlet Marx' dobbelte behandling af kapital-cirkulationen (først de »industrielle « kapitalers cirkulation i bind II og derefter i afsnit IV i bind III kapitalens cirkulation som handelskapital). Dette diskuterer vi efter analysen af revenu-formen. Også denne sidste analyse kan som formanalyse bedre gennemføres uden de komplikationer, som opstår i en mere detaljeret analyse af kapitalens cirkulation (jfr. VRAK 4).

\section{$\S 26$}

Penges bevægelse som kapital fremtræder nu i et ydre og et indre kredsløb. Den rentebarende kapitals kredsl $\phi b$ omfatter også den rene kapitals funktionsproces, som fra nu af vil blive kaldt den aktive kapitals kredsl $\phi$ :

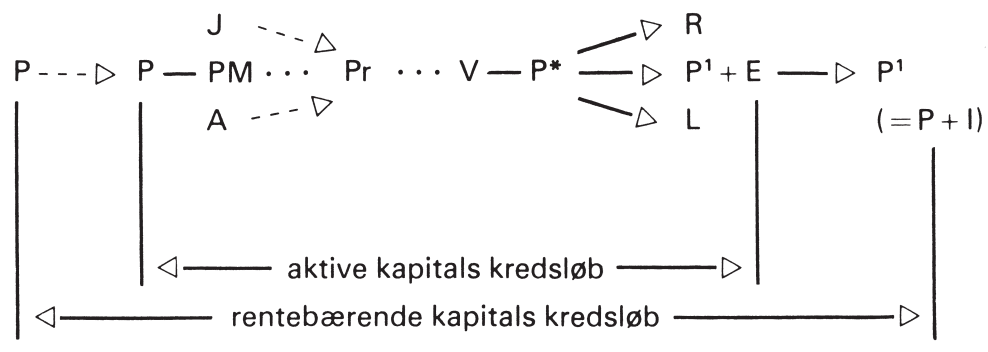

hvor P er den udlånte (- - - $\triangleright$ ) pengekapital, E er virksomhedsprofitten, som tilfalder den aktive kapitalist, I er renten, som betales til pengekapitalisten samtidig med tilbagebetalingen af den lånte pengekapital, og de $\varnothing v-$ rige symboler har samme betydning som i $\S 23$. Kapitalens ydre kredsl $\varnothing \mathrm{b}$ som rentebærende kapital kan forkortes til P - P'. Indenfor dette kredsløb forsvinder hele formidlingen af kapitalvaloriseringen gennem lønarbejdets værdiproduktion. Som rentebærende kapital fremtræder kapital helt adskilt fra kapitalens reproduktionsproces, som en tilsyneladende selvvaloriserende værdi, der forøger sig selv alene i kraft af lånerelationen. Med penges åbenbare egenbevægelse som kapital fremtræder kapital i sin mest feticherede form, dvs. som kraft i sig selv, uafhængig af nogen formidling gennem produktiv aktivitet. 
(a) Udtrykket 'aktiv kapital' anvendes normalt som en fællesbetegnelse for industriel kapital og handelskapital i modsætning til rentebærende kapital. Til og med analysen af revenu-formen begrænser vi analysen til kapitalens grundformer, som blev unders $\emptyset$ gt i VRAK 2 . Bestemmelserne - lige fra profitbegrebet $\mathrm{og}$ fremefter -, som er udviklet på grundlag af kapitalens grundformer, kan i den efterfølgende begrebslige udvikling anvendes både på industriel kapital og handelskapital.

(b) Ursula Pasero formulerer den rentebærende kapitals fetichisme på følgende måde:

»Med analysen af den 'rentebærende kapital' fremstilles nu kapitalens selvstændiggørelse overfor den materielle produktion, dens tilsyneladende løsrivelse fra denne: 'I rentebærende kapital opnår kapitalrelationen sin mest ydre og fetichagtige form. Vi har her P-P', penge som avler flere penge, selvvaloriserende værdi uden den proces, som formidler yderpunkterne' (Rh. 3, 507; K3, 404)... I den rentebærende kapitals form løser kapitalen sig i fremtrædelsesmåden P-P' overhovedet fra den materielle reproduktion; og selvom denne heller ikke »tidligere « var kapitalens mål, men blot valoriseringens middel så synes den nu at være fuldstændig udslettet.« (v. Holt/ Pasero/Roth Zur Wertformsanalyse, Frankfurt a.M. 1974, s. 119).

\section{$\$ 27$}

Pengekapitalisterne er personificeringer af de penge, som lånes ud til aktive kapitalister eller driftsherrer mod betaling i form af rente. De udgør en klasse af pengekapitalister i samme betydning som jordbesidderne udg $\varnothing \mathrm{r}$ en klasse $(\$ 21)$, - de personificerer nemlig en del af merværdien ( $\$ 13)$, som tilsyneladende har selvstændiggjort sig med sin værdiform, rente. Selv når de to figurer, den aktive kapitalist (som modtager profit fra sin virksomhed) og pengekapitalisten (som modtager rente) er sammenfaldende, fordi den aktive kapitalist opererer med sin egen kapital, opdeles bruttoprofitten tankemæssigt i rente og virksomhedsprofit, som to kvalitativt forskellige former for kapitalafkast. Overfor den indkomst, som udspringer af de aktive kapitalisters virksomhed, står kapitalens renteafkast, som tilfalder den blotte personifikation af pengekapital, som ikke har nogen direkte rolle i kapitalens reproduktionsproces.

(a) Opdelingen af bruttoprofitten i virksomhedsprofit og rente, og den heraf resulterende opdeling af kapitalistklassen i »to slags kapitalister « (Rh. 3 481; K3 383) hviler ikke på nogen subjektiv opfattelse men på det faktum »at pengekapitalist og produktiv kapitalist virkelig står overfor hinanden, ikke kun som juridisk forskellige personer, men som personer, der spiller helt forskellige roller i reproduktionsprocessen, eller i hvis hånd den samme kapital virkelig gennemløber to helt forskellige bevægelser.« (Rh.3 484; K3 385) 
Disse »helt forskellige bevægelser « frembringer to forskellige værdiformer, rente og virksomhedsprofit. Marx formulerer også disse forskellige roller i reproduktionsprocessen som forskelle i ejendomsforhold, skønt ovenstående citat fremhæver, at det ikke blot er et spørgsmål om »juridisk forskellige personer «:

»..rente ... fremtræder altså som den del af bruttoprofitten, der tilkommer kapitalejendommen som sådan. I modsætning dertil fremtræder den del af profitten, der tilfalder den aktive kapitalist, nu som driftsherregevinst, der udelukkende udspringer af de operationer eller funktioner, som han under reproduktionsprocessen udfører med kapitalen, « (Rh.3 486; K3 387)

På dette trin i fremstillingen anvender vi ikke ejendomskategorier, men reserverer denne terminologi for konkurrence-analysen, hvor de individuelle subjekter bruger de forskellige $\varnothing$ konomiske objekter som deres ejendom. For os er den vigtige pointe de forskellige roller i reproduktionsprocessen og ikke den juridiske sondring mellem ejendomsbesidder og ikke-ejendomsbesidder. Marx udtrykker de forskellige roller på flere måder:

».. driftsherregevinsten ... fremtræder (for den aktive kapitalist EHKR) udelukkende som en frugt af de funktioner, som han udfører med kapitalen, som en frugt af kapitalens bevægelse, af dens processering, en processering, han nu betragter som resultat af sin egen virksomhed til forskel fra pengekapitalistens ikke-virksomhed, ikke-deltagelse i produktionsprocessen.« (Rh. 3 486; K3 387) »Kapital uden for produktionsprocessen, der i sig selv afkaster rente, og kapital $i$ produktionsprocessen, der er processerende og afkaster driftsherregevinst.« (Rh.3 487; K3 388).

(b) Marx understreger, at opdelingen af bruttoprofitten i virksomhedsprofit og rente ikke afhænger af, hvorvidt den aktive kapitalist opererer med sin egen kapital eller ej. Han bruger i den forbindelse 'ejendoms'-terminologien i sine formuleringer:

»Også når kapitalen benytter arbejder med egen kapital, spaltes han i to personer, den blotte ejer af kapitalen og benytteren af kapitalen; « (ibid)

Der er således tale om en transsubjektiv opdeling, som overskrider den omstændighed, hvorvidt der i det enkelte tilfælde benyttes lånt kapital eller egen kapital. Dette har praktisk betydning i konkurrence-analysen på den måde, at den enkelte pengekapitalist kan vælge mellem at udlåne, hvorved han bliver ikke-deltager i reproduktionsprocessen, men trækker renter, eller selv anvende kapitalen, i hvilket tilfælde han stræber efter et afkast i tillæg til renten (jfr. Rh.3, 490; K3, 390)

(c) Sondringen mellem den aktive deltager i reproduktionsprocessen og den ikke-deltagende pengekapitalist åbner op for, at virksomhedsprofitten fremtræder som en aflønning for driften af virksomheden. Herved sløres sondringen mellem driftsherre og arbejder (jfr. § 30 ).

»I hans hjernekasse udvikler sig derfor nødvendigvis den forestilling, at hans driftsherregevinst, så langt fra at stå i nogen modsætning til lønarbejdet og at 
være lutter ubetalt fremmed arbejde, tværtimod selv er arbejdslфn, opsynsløn, wages of superintendence of labour, højere løn end den almindelige lønarbejders, 1. fordi det drejer sig om mere kompliceret arbejde, 2. fordi han udbetaler arbejdslønnen til sig selv.«(Rh.3 493f; K3 393)

(d) Det skal bemærkes, at vi, ligesom også Marx gør i behandlingen af rente- og revenueformen, antager, 1. at kapitalisterne kan opdeles pænt i to kategorier, de aktive kapitalister og pengekapitalisterne, og 2. at den lånte pengekapital kun udlægges til $\mathrm{k} \varnothing \mathrm{b}$ af produktionsmidler. Disse antagelser gøres for at kunne give en ukompliceret fremstilling af de fundamentale værdiformer. I cirkulations-analysen (VRAK4) vil dette simplificerede billede blive forstyrret: for det første med introduktionen af begrebet 'tillægskapital', som ikke kun udlægges til produktionsmidler og for det andet med den systematiske udvikling af banken, som kombinerer bestemmelserne af de aktive kapitalister og pengekapitalisterne. Banken opstår i analysen af kreditrelationerne, som udvikles gennem sammenfletningen af de individuelle kapitalers kredsløb. Bestemmelsen af klassen af pengekapitalister og af klassen af aktive kapitalister bevarer ikke desto mindre sin underliggende gyldighed, idet den for det første angiver forskellige roller i reproduktionsprocessen og for det andet udpeger forskellige fremtrædelsesformer for merværdien.

\section{$\S 28$}

En udlånt pengesum (virkelig kapital) afkaster en pengesum som rente. Kapitalisering er det praktiske resultat af pengenes rentebærende karakter; man går ud fra en regelmæssig pengeindkomst (som ikke udspringer af en virkelig kapital) og beregner en fiktiv kapital, som tankemæssigt står bag pengeindkomsten som indkomstkilde.

Hvis denne indkomstkilde kan afhændes, så kan den fiktive kapital antage virkelig pengeform som salgspris. I analogi til den rentebærende kapital gælder det, at jordrenten ( $§ 21)$ konstituerer sig som en (fiktiv) rentebarende kapital, som gennem praktisk kapitalisering antager form af jordprisen, som kan sammenlignes med hovedstolen af en pengekapital.

a. »Dannelsen af den fiktive kapital kalder man at kapitalisere. Man kapitaliserer enhver indtægt, som gentager sig regelmæssigt, idet man ud fra gennemsnitsrentefoden beregner den som det udbytte, en kapital ville afkaste, hvis den var udlånt til denne rentefod « (Rh. 3. 615; K3 484)

Enhver som har en pengesum kan udlåne den som virkelig kapital (og modtage rente) eller anvende den til at anskaffe en fiktiv kapital (og modtage pengeindkomst, hvis kapitalisering resulterer i denne fiktive kapital). Den kvalitative forskel bliver udvisket af spekulationen over kvantitative forskelle $\mathrm{i}$ alternative anbringelsesmuligheder. 
Hvis »værdiens valoriseringsbevægelse « opfattes som »det centrale tema for kapitalanalysen « (Roth i Zur Wertformanalyse 1974, s. 192 ff), så er der kun et lille skridt til understregningen af den praktisk effektive rentefetich i kapitaliseringen af pengeindkomst sammenlignet med andre former for tingsliggørelse af samfundsmæssige relationer. I penge, som kan købe en kilde til pengeindkomst, »har kapital fået sin mest tingsliggjorte form, sin rene fetich-form « (T 3 620; TüM 3 489).

b. »Jordrenten kan man forestille sig som rente på kapital. Er f.eks. jordrenten 20 og rentefoden 5, så kan man sige, at disse 20 er rente af en kapital på 400... Dermed er jorden forvandlet til kapital... Og dermed er jordrenten forvandlet til kapitalrente... De mere analytiske blandt vulgærøkonomerne indser, at prisen på jord ikke er andet end et udtryk for kapitaliseringen af jordrenten... De begriber, at denne kapitalisering af jordrenten forudsætter jordrenten, altså at jordrenten ikke kan forklares omvendt udfra sin egen kapitalisering « (T 3 648; TüM 3 511).

Rentebærende kapital er samtidig virkelig kapital, jordrentebærende kapital er kun en fiktiv kapital, selv om dens erhvervelse koster virkelige penge.

c. Den kategoriale forskel mellem værdiformerne rente og jordrente er ikke altid tydelig for den umiddelbare bevidsthed og for den politiske $\varnothing$ konomi. Dette gælder ikke kun, når det drejer sig om kapitaliseringen af jordrente, men også når det drejer sig om den jordrente, som betales for jord, der er blevet forbedret gennem investeringer. Vi har allerede antydet $(\S 22)$ hvorledes sådanne investeringer må begribes.

I et notehæfte "påbegyndt i midten af februar 1876 « skriver Marx om den forvirring omkring rente og jordrente, som opstår, når ren jordrente behandles som et renteafkast fra en i jorden anbragt kapital.

Han beskriver hvordan kapitalrente bliver jordrente, når forbedringen af jorden er permanent:

»Men jorden bærer efter den foretagne kapitalinvestering jordrente, ikke fordi der er investeret kapital i jorden, men fordi kapitalinvesteringen har gjort jorden til en mere produktiv investeringssfære, end den var tidligere... Denne jordrente, der kan opløses i penge-rente, bliver til ren og skær differentialrente, så snart den udlagte kapital er amortiseret« (Rh. 3 96f; K3 755).

\section{Revenuformen.}

\section{$\S 29$}

De aktive kapitalister råder over elementerne i den kapitalistiske produktionsproces (arbejdere, jord og produktionsmidler) i kraft af de lånerelationer, som de har indgået med henholdsvis arbejderne, jordbesidderne og pengekapitalisterne. 
Denne paragraf opsummerer udviklingen indtil nu. Det bør bemærkes at vi på dette trin konsekvent har undgået brugen af juridisk terminologi. Lånepriserne på produktionselementerne, arbejdere og jord er økonomiske objekter på samme måde som priserne på de industrielle varer. Den hidtidige fremstilling kan opsummeres som følger: Fem værdiformer er blevet udviklet: værdien af den industrielle vare/penge, løn, jordrente, rente og virksomhedsprofit, og i forlængelse heraf er de tre produktionselementer blevet behandlet. Denne begrebslige udvikling gør det med det samme klart, at man ikke kan fremstille nogen simpel sammenhæng mellem tre produktionselementer og tre revenuer (jvf. § 32a). I revenu-formsanalysen (og i de senere dele af analysen af den kapitalistiske samfundsform) udvikles ikke nye værdiformer, (men der udvikles højst kombinationer af disse i systematisk forstand basale værdiformer i cirkulations- og konkurrenceanalysen). I revenuformen tematiseres en fælles bestemmelse af de tre værdiformer løn, jordrente og rente, der skjuler den kendsgerning, som er blevet tydeliggjort i løbet af den hidtidige systematiske argumentation, nemlig at der er tale om afledede værdiformer, faktisk om »fiktive værdier «, »imaginære størrelser « (Rh. 1, 206; K1, 117). Marx, og også vi, $\emptyset$ nsker imidlertid at behandle denne tilsløring som en konstitutiv illusion ved det kapitalistiske samfund.

\section{$\S 30$}

De skikkelser, der står overfor driftsherren, har det fælles kendetegn, at de alle modtager en regulær godtgørelse fra lånerelationen. På trods af alle deres forskelle muliggør dette, at løn, jordrente og rente kan indordnes under et fælles begreb som revenuer. Stillet overfor disse revenuer er virksomhedsprofit et ikke-revenu. Der tages et skridt i retning af overfladen af den kapitalistiske $\varnothing$ konomi ved at knytte revenuerne til tre revenu-kilder, hvorved hvert revenu springer fra sin egen kilde. Produktionsprocessen er således på den ene side præsenteret som de tre revenukilders (arbejdere, jord og pengekapital) separate eksistens, og på den anden side deres fungerende enhed som arbejdsproces (fra hvilken virksomhedsprofitten, der er et ikke-revenu, flyder). Hvorvidt disse pengestrømme flyder, er naturligvis betinget af de tre produktionselementers succesfulde samvirke $\mathrm{i}$ produktionsprocessen, og af anerkendelsen af denne produktive aktivitet gennem produktets værdiform. I revenuerne er denne anerkendelse imidlertid allerede praktisk forudsat.

I og med at hvert revenu springer fra sin egen revenukilde, kan man stille det yderligere spørgsmål, hvorvidt hvert revenu kan forstås som flydende fra en fiktiv kapital. Marx kalder »den rentebærende kapital som sådan moderen til alle forrykte former «. Vi har set $(\S 28)$ at revenukilden jord kan kapitaliseres. Hvis lønnen imidlertid

»opfattes som rente og arbejdskraften således som kapital, der afkaster denne rente ... (så) er der her to omstændigheder, der på ubehagelig vis krydser denne 
tankeløse forestilling; for det første, at arbejderen må arbejde for at opnå denne rente, og for det andet, at han ikke kan omsætte kapitalværdien af sin arbejdskraft i penge«. (Rh 3, 614 f; K 3, 483 f) »Det forrykte i den kapitalistiske betragtningsmåde når her toppen, for $\mathrm{i}$ stedet for at forklare kapitalens valorisering ud fra udbytningen af arbejdskraften, bliver arbejdskraftens produktivitet omvendt forklaret ved, at arbejdskraften selv er denne mystiske ting, rentebærende kapital« (ibid.).

Lønnens kilde er ikke 'kapital' men - og her refererer vi til hverdagsantagelsen, som udtrykker revenu-modtagerens standpunkt - 'arbejde'. Skønt løn i analysen af produktionsprocessen blev begrebsliggjort som låneprisen for at stille arbejderens arbejdskraft til rådighed for kapitalisten, så er denne stillentil-rådighed sløret for låneren af dette produktionselement gennem arbejderens aktivitet i den aktive kapitalists arbejdsproces, dvs. gennem arbejderens 'arbejde'. 'Arbejde' er her reduceret til en blot individuel aktivitet og fordrejer således begrebet om arbejdsprocessen. 'Kapital' som en sum af penge og 'arbejde' som aktivitet fremtræder således som revenukilder for den ureflekterende bevidsthed. I triaden af revenukilder er den ene virkelig kapital, den anden fiktiv kapital og den sidste hverken fiktiv eller virkelig kapital. Arbejderen kan ikke betragtes som en fiktiv kapital, hvis et kendetegn ved kapitaliseringen skal være den faktiske eksistens af en salgspris for revenukilden (som en virkelig sum penge-'kapital'). Det er snarere arbejderen, som er revenukilde. I den dagligdags forståelse er dette vulgariseret til 'arbejde' som revenukilde. Denne vulgarisering muliggør at distinktionen mellem arbejder og driftsherre udviskes (jvf. § 27c). Hvis aktiviteten i arbejdsprocessen bliver kendetegnet på en revenukilde, så synes den aktive kapitalist i samme omfang som lønarbejderen at være en arbejder, som trækker løn fra virksomheden for sin aktivitet. Med udgangspunkt i opdelingen af kapitalisten i »to slags kapitalister « argumenterer Marx på en utilfredsstillende måde for den aktive kapitalists illusoriske fremtræden som arbejder:

»Kapitalen selv bliver spaltet. For så vidt den er forudsatning for den kapitalistiske produktion, for så vidt den altså udtrykker arbejdsbetingelsernes fremmedgjorte form, et specifikt samfundsmassigt forhold, så realiserer den sig i renten. Den realiserer sin karakter som kapital i renten. På den anden side, for så vidt den fungerer i processen, fremtræder denne proces som adskilt fra dens specifikke kapitalistiske karakter, fra dens specifikke samfundsmæssige bestemthed - som den blotte arbejdsproces overhovedet. For så vidt kapitalisten således griber ind i denne, griber han ikke ind i den som kapitalist, thi hans karakter som sådan er diskonteret i renten, men som arbejdsprocessens funktionær overhovedet, som arbejder, og hans arbejdsløn udtrykker sig i den industrielle profit (Marx' udtryk for virksomhedsprofit på det tidspunkt, EHKR). Det er en særegen arbejdsform - ledelsesarbejde - men arbejdsformerne er jo overhovedet forskellige fra hinanden.«(T3, 614; TüM 3, 484).

Problemet ligger ikke i, at den kapitalistiske arbejdsproces fremtræder som en form-ubestemt arbejdsproces (eftersom arbejdsprocessens kapitalistiske karakter fremtræder ligeså meget i lønformen som i renteformen), men 
i 'forglemmelsen' af bestemmelsen af lønarbejde. På trods af denne sammensmeltning af rollerne som arbejder og driftsherre i den dagligdags bevidsthed, så fastholder vores fremstilling-distinktionen mellem de to karaktermaskers roller, og fastholder således også distinktionen mellem løn som revenu og virksomhedsprofit som ikke-revenu. Denne distinktion bliver vigtig i udviklingen af kategorien 'konkurrence-subjekt' i begyndelsen af konkurrenceanalysen.

\section{$\S 31$}

Revenuerne svarer til dele af vareværdierne, eftersom de er udbetalt fra udbyttet af salget af produktionsprocessens vareprodukter. De kan således opfattes som distributionsformer af værdien. Revenuernes forbindelse med revenukilderne konstituerer imidlertid en anden relation. De afledende værdiformer (løn, jordrente og rente) fremtræder i denne relation ikke som dele af værdien, men som pengesummer, der stammer fra tre forskellige pengekilder. $I$ lønrelationen er arbejderen en kilde til revenu. De formidlende trin udslettes når revenuet knyttes til dets revenukilde. Revenuerne bliver således tilsyneladende konstitutive bestanddele af vareværdien. Revenukilderne/revenuerne er hermed de primære og vareproduktets pris/værdi er en sammensætning af revenuer, udlagt kapital og virksomhedsprofit, og er således sekundær. Den praktiske forudsætning om revenuerne som garanterede ( $(30)$ anvendes således teoretisk til at negere værdiformens rolle i konstitueringen af værdisubstansen.

Marx kritiserer Smith for at svinge mellem arbejdsværditeoriens »esoteriske« position og den »komplet forkerte doktrin«, at vareværdien kan opløses i priserne på produktionselementerne. Med revenukilde-fetichismen gør en yderligere forskel mellem arbejdsværditeorien og værdiforms-analyse sig gældende.

For arbejdsværditeorien ligger revenuformens mystificerende karakter i den kendsgerning, at det fremtræder, som om vareproduktets bytteværdi (pris) er bestemt ved summen af revenukomponenter plus en margin til driftsherren. Hertil hævder arbejdsværditeorien, at det tværtimod er (det samfundsmæssigt nødvendige) arbejdsindhold alene som bestemmer varens værdi og følgelig også dens bytteværdi. Ved et kunstgreb identificeres arbejde med arbejdernes aktivitet uafhængigt af andre arbejdselementer: ${ }^{1}$ Relationen mellem væsenet og dets mystifikation forstås som en relation mellem arbejderen, som den ene-

1. Uklarheden i specifikationen af arbejdet og arbejdselementerne findes allerede i undersøgelsen af arbejdsprocessen i 1. bind. Marx skriver der: »De simple elementer i arbejdsprocessen er den formålsrettede aktivitet eller arbejdet selv, arbejdsgenstanden og arbejdsmidlerne.« (Rh. 1, 303; K1, 193) Denne formulering er misvisende i henseende til at identificere arbejderen med »formålsrettet aktivitet«. Dette bliver afgørende i begrebsliggørelsen af produktionsmidlernes rolle i produktionsprocessen. Marx behandler dem forkert som værdi, der er »overført« i løbet af produktionen. (Jvf. § 18b) 
ste kilde til værdi (hvorved de andre produktionselementer ikke skaber nogen værdi), overfor en opfattelse i følge hvilken alle produktionselementer skaber værdi. Dette kan imidlertid ikke være pointen i fetichismen, fordi arbejderen, som enkel faktor i produktionsprocessen, ikke kan skabe værdi; arbejde er altid et samvirke af alle tre produktionselementer. Værditeorien kan ikke være et spørgsmål om at udsondre et enkelt produktionselement som værdiskaber og neglicere alle andre.

For værdiformsanalyse er det i modsætning hertil ikke et spørgsmål om at udnævne arbejde som 'kilde' til varens værdi eller bytteværdi i modsætning til 'værdiens' forskelligartede 'revenukilder' (hvilket er et fuldstændigt irrationelt udtryk). Det drejer sig tværtimod om mystifikationen i at varen, som udtryk for det samfundsmæssige arbejde, fremtræder som om vareprisen er sammensat af priserne på de forskellige produktionselementer; dvs. vareprisen er ikke længere, som ved fremstillingens start (jvf. VRAK 1) forstået som værdiform, som form for samfundsmæssigt arbejde, men er simpelthen opsplittet i andre priser. I denne forstand er revenuformsanalysen en analyse af overfladen, hvor forbindelsen til værdisubstansen er erstattet af en cirkulær relation mellem faktorpriser og produktpriser. Værdiforms-analysen bryder denne cirkel.

\section{$\$ 32$}

Revenukilde-triaden må skelnes fra produktionselements-triaden. Denne forskel er forårsaget af pengekapitalen, der først må forvandles til produktionsmidler (arbejdsredskaber, råmaterialer, hjælpematerialer) gennem købet af industrielle varer før det tredie produktionselement, ved siden af arbejderne og jorden, kan stå til rådighed for den aktive kapitalist. Der er således ikke tale om en uhellig treenighed, som forskellige udgaver og fremstillinger af den »trinitariske formel « hævder, men om en $\varnothing$ konomisk kvadrupel af penge-indtjenere. Denne kvadrupel er imidlertid ikke symmetrisk, fordi driftsherren har en speciel rolle; det er snarere passende med en trojka formel, hvor driftsherren kører med tre heste, som han har spændt for og styrer fremad mod monetære belønninger.

Trojka formlen afskiller sig fra Marx' trinitariske formel i kapitel 48 i 3. bind af Kapitalen. Årsagen til dette er, at Marx ikke er tilstrækkelig opmærksom på de fire figurer, der optræder på dette niveau. Fordoblingen af kapitalisten i driftsherre og pengekapitalist, som han udvikler i kapitel 21 (i følge Engels editering), bliver ikke taget $\mathrm{i}$ betragtning $\mathrm{i}$ forsøgene på at formulere den trinitariske formel. Marx er naturligvis på det rene med de fire figurer og de fire indkomstkategorier og anvender derfor svingende formuleringer, hvor snart renten, snart profitten gives fortrin. Vi vender os derfor mod en nærmere vurdering af kapitel 48.

Marx begyndte det sidste afsnit af Kapitalen, »Revenuerne og deres kilder « i det originale manuskript (manuskript A80 i Amsterdam arkivet, pp. 528-531, 
hul, 534-539) svarende til den regel som Engels kortfattet formulerer i forordet til tredie bind: »Som en regel var begyndelsen af hvert afsnit udarbejdet temmelig omhyggeligt, selv for det meste stilistisk afrundet. Men jo længere man kom jo mere skitseagtigt og mere fragmentarisk blev udarbejdningen.." (Rh. 3, 9; K3, 8). Eftersom begyndelsen altså også her er udarbejdet, er det forbavsende at Engels placerer fem sider, der indeholder »tre fragmenter «, i begyndelsen. Fragment I er taget fra A80 p. 470f, fragment II følger derpå fra A80 p. 471 og fragment III står på et tidligere sted i hovedmanuskriptet, A80 p. 445. Under overskriften (som er Marx') 'Den trinitariske formel' gør Engels kun følgende bemærkning: »De følgende tre fragmenter blev fundet forskellige steder i manuskriptet til afsnit VI.« Det originale sted for fragment I og II er, så vidt vi kan se, kladden til det umiddelbart forudgående kapitel 47 'Den kapitalistiske jordrente tilblivelse' (jvf. Rh. 3, 1039 ff; K3, 816ff). Fragment III, mener vi, stammer fra kladden til kapitel 46, som Engels gav den sammensatte overskrift 'Byggegrundrente. Bjergværksrente. Jordpris.' (A80 p. 437-447). Passagen, der er trykt Rh. 3, 1002-03; K3, 787 (»At sætte en del af merværdien ... det rationelle, og dets rationelle element er selve irrationaliteten. «) hører såvel stilistisk som indholdsmæssigt til dette fragment.

Teksten til kapitel 48, der begynder på A80 p. 528 (Rh. 3, 1053; K3, 826), starter med en skitse af gangen i argumentationen i kapitalanalysen. Endnu en rekapitulering kommer nogle få sider senere på A80 p. 535-539 (Rh. 3, 1064-1070; K3, 835-839) med hvilken teksten udgivet af Engels på samme vis bryder af. (Det er muligt, at der er gået sider tabt her. Begyndelsen af kapitel 49 er fra A80 p. 542). Den første skitse af hele gangen i argumentationen understreger først profittens spaltning i virksomhedsprofit og rente (Rh. 3, 1056; K3, 828) og forklarer, at merværdien »under disse to kategorier kan tilfalde forskellige slags kapitalister « (her er der allerede en antydning af en svingen). Skitsen sluttes med en første version af den trinitariske formel: »Kapitalen afkaster år efter år profit til kapitalisten, jorden jordrente til jordbesidderen, og arbejdskraften - under normale forhold og så længe den er en brugelig arbejdskraft - løn til arbejderen. Disse tre værdikomponenter af den årligt producerede totalværdi og de tilsvarende komponenter af det årligt producerede totalprodukt kan ... konsumeres af deres respektive besiddere, uden at kilden til deres reproduktion tørrer ud. De fremtræder som årligt konsumerbare frugter af et stedsegrønt træ eller rettere sagt af tre træer; de udgør den årlige indkomst for tre klasser, kapitalisterne, jordejerne og arbejderne, revenuer som den aktive kapitalist fordeler i sin egenskab som den umiddelbare udpumper af merarbejdet og anvender af arbejdet overhovedet. « (Rh. 3, 1057f; K3, 829f) Kapitalist, jordejer og arbejder er udpeget som revenu-modtagere.

Reduceret til nøgleordene kan denne passage skrives som formlen »kapital - profit, jord - jordrente, arbejdskraft - $1 \varnothing n \ll$. Sondringen mellem de to slags kapitalister, der blev nævnt tidligere, foretages ikke længere. Eftersom de tre revenuer her konstituerer nyværdien, er der ikke nogen værdikomponent tilovers til virksomhedsprofitten. Ikke desto mindre dukker driftsherren op igen i slutningen af citatet med den specielle rolle, som »anvender af arbej- 
det« og fordeler af revenuerne. Og dette er helt klart indiskutabelt. Heri ligger imidlertid også en indrømmelse af, at der her er tale om fire personifikationer og ikke tre.

Længere nede argumenterer Marx videre:

»Distributionen forudsætter tværtimod denne substans (den distribuerede værdisubstans, EHKR) som forhåndenværende, nemlig årsproduktets totalværdi, der ikke er andet end genstandsgjort samfundsmæssigt arbejde. Det er imidlertid ikke i denne form, sagen fremtræder for produktionsagenterne, bærerne af de forskellige funktioner i produktionsprocessen, men derimod i en fordrejet form «. (Rh. 3, 1958; K3, 830)

Vi formoder, at forklaringen af denne fordrejning, som falder Marx ind, afholder ham fra at tage den allerede udviklede fordobling af den kapitalistiske figur i betragtning, og fra tydeligt at præcisere nyværdiens fire værdikomponenter: de tre revenuer og virksomhedsprofitten. Kritikken af vulgær- $\varnothing$ konomien spiller givet en medvirkende rolle, hvilket kan have fået Engels til at indskyde fragment III; men det systematiske argument må være i stand til at bære selvstændigt.

Den anden version af den trinitariske formel kan stykkes sammen fra A80 p. 534 (Rh. 3, 1059f; K3 831f), dvs. teksten efter hullet i manuskriptet:

$»$ Jord - jordrente«, »arbejde - $1 \varnothing n \ll, »$ kapital - profit« (hvor der i behandlingen af det første par »jord - jordrente« må være gået nogle sider tabt). Tidligere står der (Rh. 3, 1057; K3, 829): »Så vidt forskelligt disse relationer ellers kan fremtræde, har de dog alle ét til fælles«. Herpå følger den ovenfor citerede første version af den trinitariske formel. Senere (Rh. 3, 1060; K3, 832) finder vi en tilsvarende formulering, som imidlertid er efterfulgt af et argument - og her gives en henvisning til den anden version af den trinitariske formel - der antyder, hvorledes Marx forklarer den »fordrejede form « i hvilken »sagen fremtræder for produktionsagenterne «:

»Når vi for det første bemærkede, at de tre kilder er forskelligartede, så ser vi nu for det andet, at deres produkter, deres afkom, revenuerne, tværtimod alle tilhører samme sfære, værdiens sfære. Imidlertid udlignes dette ... ved, at kapitalen faktisk, ligesom jorden og arbejdet, betragtes alene i sin stoflige substans «. (Rh. 3, 1060; K3, 832)

Vi har forkortet den anden sætning betragteligt for at kunne fremhæve den nye tanke: profit, jordrente og løn springer fra kapital, jord og arbejde »taget i deres stoflige substans«. Den gisning, vi allerede har fremsat, er, at forsøget på at udfylde denne tanke har bevæget Marx til at reducere nyværdiens fire værdikomponenter og deres personifikationer til tre. Denne idé om sammenfaldet mellem revenukilder og stoflige eller materielle produktionselementer formuleres i successive variationer på de følgende sider (Rh. 3, 1060-1064; K3, 832-834) og ender - før den anden skitse af kapitalanalysen - med en note om den eksoteriske Smith og vulgærøkonomen Storch:

»Løn, profit og jordrente er de tre urkilder til al indkomst såvel som til al bytteværdi « $($ Smith) »Således er årsagerne til den materielle produktion tillige også kilderne til de oprindelige revenuer, der findes« (Storch) (Rh. 3, 1064; K3, 834). 
Og det er her, fragment III hører til i følge dets indhold, og ligesådan den korte én-sides passage (Rh. 1068f; K3, 838f), der slutter den nævnte anden skitse af kapitalanalysen og som beskriver »den umiddelbare sammenvoksen af stoflige produktionsrelationer med deres historisk-sociale bestemthed « som »hverdagslivets religion «, hvorved den klassiske $\varnothing$ konomi fremstår som religionskritik og vulgærøkonomien som teologi.

Tre-tre metaforen er ikke vellykket fordi revenukilden kapital må forstås som rentebærende kapital, hvilket blokerer for dens identifikation med de stoflige produktionsmidler. Disse afkaster i følge Marx profit - men profit er ikke et revenu, for som han selv siger:

»Renten, ikke profitten, fremtræder således som kapitalens vardiskaben, der strømmer fra kapitalen som sådan og derfor fra den blotte ejendom over kapital; derfor (er renten, EHKR) det revenu som egendommeligt skabes af kapitalen.« (T3, 575; TüM 3, 453)

Man må altså rettere bruge den ovenfor nævnte trojka formel $(\S 32)$ for at sammenfatte de fire indkomster i en passende metafor, hvor man samtidig kan holde revenuerne billedligt adskilt fra den fjerde indkomst, virksomhedsprofitten. ${ }^{2}$

\section{$\$ 33$}

Karaktermaskernes kvadrupel, som er bragt sammen gennem lånerelationer, og som muligg ør at den kapitalistiske produktionsproces kan komme i stand, udgør basis for de fire klasser i den kapitalistiske produktionsmåde. De fire klasser korresponderer til de fire adskilte roller hos agenterne, der sætter produktions-processen i sving, og som på sin side korresponderer til fire adskilte værdiformer.

a) »På overfladen fremtræder alting fordrejet«. Med hensyn til klassedelingen, som den fremtræder på overfladen, har denne fordrejning følgende effekt: i analysen af væsenet er der to klasser - klassen af udbyttere af merværdi (og her »repræsenterer kapitalisterne alle, der deltager i rovet « (Rh. 1, 802; K1, 590)) og arbejderklassen. I analysen af overfladen er der fire klasser, fordi merværdien (den residuale, jvf. § 14) i mellemtiden er blevet spaltet i tre dele (virksomhedsprofit, jordrente og rente). Det har imidlertid den konsekvens, at den fundamentale klassemodsætning forsvinder bag de forskellige klasseforskelle, dvs. i deres mangfoldighed. Een brist i dette overfladisk set indbydende billede af en alsidig konkurrence (som vil blive uddybet i konkurrenceanalysen) ligger i de forskellige muligheder for kapitalisering, som allerede omtalt i $\S 30$. Den fundamentale opdeling i to klasser fremtræder ud fra dette standpunkt som en modsætning mellem de »besiddende klasser « (de rige) og arbejderklassen (de fattige). Selv denne dualisme træder imidlertid i baggrunden for så vidt som arbejderklassen

2. Vores kritik af Marx' trinitariske formel er blevet udviklet på basis af diskussioner om et arbejdspapir af Herbert Ruenzi, Zur Ableitung von Recht und Staat, dubl. Konstanz Universitet 1978. 
og klassen af aktive kapitalister fremtræder som dem, der lever af deres aktivitet i modsætning til de to ikke-aktive klasser, jordbesiddere og pengekapitalister. Som vi har set i analysen af produktionsprocessen (VRAK 2), hviler den fundamentale klassemodsætning på, at arbejdsprocessen domineres af kapitalens proces. På overfladen fremtræder denne objektive modsætning som et modsætningsforhold mellem sociale grupper.

b) Råmanuskripterne fra 1864-65, som Marx skrev til tredie bind af Kapitalen, slutter med én side som begyndelse til kapitlet 'Klasserne'. Han skriver om »ejerne af den blotte arbejdskraft, ejerne af kapital og jordejerne« som »danner de tre store klasser i det moderne samfund, der beror på den kapitalistiske produktionsmåde« (Rh. 3, 1137; K3, 892). Et afsnit senere stiller han spørgsmålet: »hvad danner en klasse? « og afviser tilsyneladende svaret »revenuerne og revenukildernes ensartethed « (Rh. 3, 1137f; K3, 893). Man må formode, at Marx har haft produktionsrelationerne, som modsvarer revenukilde-lånerelationerne, $\mathrm{i}$ tankerne. På denne baggrund ville 'klasserne' af »læger og embedsmænd « blive udelukket fra betragtningen som sociale klasser, som Marx antyder på de sidste linier før manuskriptet bryder af. Kun personifikationen af roller i den kapitalistiske produktionsproces kan tilskrives et klassemedlemskab (se pkt. c nedenfor). Det er væsentligt, at det eneste kapitel i Kapitalen, der har overskriften »Klasserne« findes på niveauet for revenuforms-analysen, hvor merværdien allerede begrebsmæssigt er blevet spaltet i et antal værdiformer. Den klasseanalyse, som Marx antyder, overskrider således niveauet for analysen af produktionsprocessen i bind 1, hvor der kun forekommer to klasser.

Den kritik af Marx' trinitariske formel, som vi har udviklet ovenfor, implicerer også en kritik af hans klasseanalyse, idet vi når frem til det resultat, at der er fire basale klasser og ikke tre.

c) Den klassestruktur, som afdækkes på revenuform-analysens niveau, hviler på de fire $\varnothing$ konomiske karaktermasker, der fremtræder som funktionelle i forhold til eller som forud givne betingelser for den kapitalistiske produktionsproces. Denne fire-folds distinktion vil i stigende grad blive tilsløret på senere analyseniveauer, hvor de forskellige $\varnothing$ konomiske roller flyder ind over hinanden. Det sker i første omgang i cirkulationsanalysen, hvor banksystemet introduceres. Pengekapitalisterne spaltes da i den aktive finansmand i banken på den ene side, og på den anden side de passive indlånere, der til gengæld i varierende omfang består af medlemmer af alle klasser. Yderligere tilsløringer sker i konkurrenceanalysen med udviklingen af begrebet om aktieselskabet og som et ledsagefænomen begrebet om manageren, hvor kategorierne driftsherre og arbejder flyder sammen. I tillæg hertil opstår der forskellige kombinationer, når det samme individ omfatter et antal af økonomiske roller, f.eks. når driftsherren opererer med sin egen pengekapital eller jord. Marx refererer selv til dette sammenfald af $\emptyset$ konomiske roller, når han nævner »klassestrukturen « i 1800-tallets England, hvor »mellemog overgangstrin også her tilslører ... grænsebestemmelserne overalt«. (Rh. 3, 1137; K3, 892) En endelig opløsning af klasseanalysen finder sted med analysen af staten, hvor der opstår sociale roller (f.eks. embedsmænd), som ikke direkte er en del af 
den kapitalistiske $\varnothing$ konomi og hvor alle samfundsmedlemmerne behandles som abstrakt lige, som personer, af staten.

\section{$\S 34$}

Analysen af værdiformernes revenuform omhandler karakteristiske træk ved den kapitalistiske virkelighed, som har det resultat, at sammenhængen, som er præsenteret $i$ vareanalysen og i analysen af den kapitalistiske produktion, ikke fremtræder som sådan for deltagerne i den kapitalistiske $\emptyset$ konomi. Den kritiske, systematiske tænkning hævder med denne udvikling at have demonstreret - ganske vist kun ved at udfolde præsentationen gennem en dialog - at den umiddelbare bevidsthed er en moderne, feticheret form for taenkning. Man kan således lave en bred skelnen indenfor den systematiske præsentation mellem 'analysen af væsenet' (som er indeholdt i VRAK 1, 2 og $3 \S \S 1$-28) og 'overfladen', som skjuler dette væsen, men samtidig realiserer det. Med revenuformsanalysen er det kun ét karakteristisk træk ved denne overflade, der er blevet udviklet. Yderligere mystifikationer og fordrejninger vil blive begrebsliggjort $i$ analysen af den udfoldede cirkulation (VRAK 4, partikulariseringen af kapitalens proces) og i analysen af den kapitalistiske konkurrence (subjektiveringen af den $\varnothing$ konomiske proces).

a) Læseren vil have bemærket, at den systematiske placering af revenuformanalysen hér adskiller sig fra den, som Marx har givet i manuskripterne til tredie bind fra 1864-66. Vi synes, det er velbegrundet at behandle værdiformernes revenuform direkte efter deres udvikling i analysen af den kapitalistiske produktion, hvor vi har behandlet alle tre produktionselementers værdiformer. Revenuform'sammendraget' af analysen af værdiformerne kan præsenteres på basis af et simpelt kapitalkredsløb, som det er opridset i diagrammet i § 26, uden de komplikationer som opstår, når kapitalen er opdelt og anlagt som tillægskapital.

b) I manuskripterne fra 1861-63 antyder Marx en systematisk struktur for 1. bind af Kapitalen, hvor en behandling af revenuerne er placeret mellem analysen af produktionsprocessen og analysen af kapitalakkumulationen:

»Efter den relative merværdi skal kombinationen af den absolutte og den relative merværdi behandles. Så størrelsesforholdet for stigning og fald. Efter det, eller snarere før det, den ændring, som produktionsmåden selv undergår, når den bliver kapitalistisk. Ikke længere blot formel subsumtion af arbejdsprocessen under kapitalen... Herefter skal det omfang i hvilket kapitalen er produktiv præsenteres, hvilket er forbundet med spørgsmålet om produktivt og uproduktivt arbejde. Så arbejdslønnen og merværdien som revenu, revenuformen overhovedet, hvad der er nødvendigt for os for overgangen til kapitalens akkumulation. $\ll^{3}$

3. MEGA II. 3.1 Berlin 1976, p. 285. 
Marx refererer i denne passage til en logisk-historisk begrebslig udfoldelse, som faktisk er gennemført i 1. bind af Kapitalen. Henvisningen til »revenuformen i almenhed « er flertydig, og i vores vurdering refererer den ikke til den egentlige revenuformsanalyse, dvs. til Marx' trinitariske formel, fordi der på dette sted ikke er nogen begreber om jordrenten og renten. I 1. bind af Kapitalen, kapitel 22 'Forvandlingen af merværdi til kapital', afsnit 3 'Deling af merværdi i kapital og revenu. Abstinensteorien', betragtes revenu udtrykkeligt som den del af merværdien, som kapitalisten konsumerer i den individuelle konsumption. Marx nævner den dobbelte brug af termen »revenu«: »... ordet 'revenu' bliver brugt i dobbelt betydning, først om merværdien som en periodisk frugt af kapitalen, dernæst for at betegne den del af denne frugt, som kapitalisten periodisk forbruger... Jeg bibeholder denne dobbeltbetydning...« (Rh. 1, 835; K1, 618).

For Marx er kategorien revenu således kun relevant for »overgangen til akkumulationen « i den forstand, at den udtrykker den del af merværdien, som ikke står til rådighed for akkumulation.

\section{Appendiks}

\section{Om sekundærlitteraturen til revenuformanalysen.}

Kritikken af Marx' fremstilling på »revenu-niveauet «, som er skitseret ovenfor, er i lige stor udstrækning dækkende for begge tekster med titlen »Revenuet og dets kilder «, dateret henholdsvis oktober-november 1862 (i T3 564-669; TüM 3, 445528 og 604) og den sidste del af 1864-65 manuskriptet til 3. bind af Kapitalen. Man kunne vel forvente, at sekundærlitteraturen til Kapitalen har undersøgt dette analyseniveau kritisk.

Den 677 sider store »Kommentar til Theorien über den Mehrwert« som den vestberlinske projektgruppe »Entwicklung des Marxschen Systems « har udgivet under den rammende titel »Der 4. Band des 'Kapital'? «(Westberlin 1975) gengiver først Marx' formuleringer om rente og virksomhedsprofit (p. 61 1f) og vender sig så mod afsnittene fra 1861-63 manuskripterne for at diskutere spørgsmålet i hvilken udstrækning den aktive kapitalist modtager løn, som et led i den produktive totalarbejder. De kommer til følgende konklusion:

»Men selv hvis man ser bort fra dette aspekt, hvor kapitalisten selv spiller en aktiv rolle $\mathrm{i}$ arbejdsprocessen, så er den del af indtægterne, som kapitalisten modtager for at udføre funktioner indenfor valoriseringsprocessen, som udspringer af klassemodsætningen, en del af den variable kapital«. (p. 612)

Vi har her et standpunkt, som hævder, at der bag virksomhedsprofittens fremtrædelse som virksomhedsløn ligger en forvandling af merværdien til variabel kapital! Denne fortolkning står i kras modsætning til Marx' behandling af den aktive kapitalists rolle, når han betragtes som leder af arbejdsprocessen og dermed som part af totalarbejderen:

»Den ... oprindelige bestemmelse af det produktive arbejde, der er afledet af selve den materielle produktions natur, er fortsat gyldig for totalarbejderen som 
totalitet betragtet. Men den gælder ikke længere for de enkelte af totalarbejderens led betragtet enkeltvis... Kun den arbejder er produktiv, der producerer merværdi for kapitalisten «. (Rh. 1, 723; K1, 532)

Originalerne til den store manuskript fra 1861-63, som indtil videre kun er delvis publiceret, ligger i Moskva. Witali S. Wygodski, som har arbejdet på MarxEngels Instituttet (i dag Institut for marxisme-leninisme) i Moskva har fremhævet perioden 1850-1863 som særlig vigtig i sin bog »Die Geschichte einer grossen Entdeckung "(tysk: Berlin 1967, russisk: Moskva 1965). Men han behandler ikke revenuformanalysen. Wygodski's næste bog »Wie Das Kapital entstand « (Moskva 1970, Frankfurt 1976) som af ham selv beskrives som en »direkte fortsættelse « (p. 11) af den første bog, giver en omfattende vurdering af det andet udkast til Kapitalen (1861-63). I den kronologiske oversigt over Marx' arbejde med Theorien über den Mehrwert (p. 93) er perioden »oktober-november 1862 « ubeskrevet. Marx' Notebog XV behandles uden hensyntagen til, at den første udgave af revenuformanalysen er indeholdt heri. I sin diskussion af det tredie udkast (p. 92) til Kapitalen (1863-65), som indeholder »den eneste variant af 3. bind « lader Wygodski revenuerne upåagtet og runder hele emnet af $\mathrm{i}$ to sætninger uden at problematisere det og med en ensidig fremhæven af »de herskende klassers interesse $\ll$ (p. 122).

Roman Rosdolsky, som arbejdede på Marx-Engels Instituttet i Moskva fra 1927-1931 og som ganske givet var bekendt med »råudkastet til Kapitalen 1857-1858 « fra det tidspunkt, hvor det blev forberedt til trykning, behandler i sin bog "Zur Entstehungsgeschichte des Marxschen Kapital « ${ }^{4}$ på pp. 46-49 den trinitariske formel i den borgerlige $\varnothing$ konomi. Han kommenterer passager fra Theorien del 3 og Kapitalen bind 3, hvor han lægger vægten på spørgsmålet om betydningen af »distributionsformerne « overfor produktionsformerne. I et konkluderende afsnit (p. 49-54) med titlen »De tre fundamentale samfundsmæssige klasser « er den skiftende betydning af kapitalisten og jordbesidderen understreget. Rosdolsky afgrænser kapitalisten til driftsherren og nævner ikke, at en stor del af Marx' polemik mod jordbesidderne kan føres over på pengekapitalisterne.

Ernest Mandel, som taler meget rosende om Rosdolsky (p. 68, 101) i sin bog »The formation of the economis thought of Karl Marx « (New York 1971), overser revenuformanalysen, selv i hans meget omfattende kapitel om fremmedgørelse. Dette er også tilfældet med stort set hele den sekundærlitteratur om Marx, som Mandel diskuterer og kritiserer.

Helmut Reichelt refererer indholdsmæssigt til Rosdolsky i sin bog »Zur logischen Struktur des Kapitalbegriffs bei Karl Marx« (F/M 1970) ${ }^{4 a}$. På dette tidspunkt,

4. Manuskriptet var færdigt i 1955, men blev først trykt i Frankfurt 1968. Dansk oversættelse: Kapitalens tilblivelseshistorie, Aarhus 1977.

4a. Dansk udgave: Kapitalbegrebets logiske struktur hos Karl Marx, København 1974. 
ved begyndelsen af det årti, der fremkaldte den tyske »statsafledningsdebat«, var der en voksende interesse for diskussionen om, hvorledes de kapitalistiske produktionsrelationer fremtræder på overfladen, niveauet for revenuerne. Reichelt understreger den trinitariske formel som »udgangspunktet for videnskaben om den politiske $\varnothing$ konomi (p. 88; da. p. 108) og kritikken heraf som konklusionen på Kapitalen. Hverken det iøjnefaldende træk ved den citerede variant af formlen, »Kapital - rente ... rente (i stedet for profit)«, eller eksistensen af andre varianter af formlen, eller utilstrækkelighederne i Marx' »analyse af kapitalens overfladestruktur« (ibid.) tematiseres hos Reichelt.

Erlangen-gruppen »Marxistische Gruppe/Theorifraktion«, der er inspireret af såvel Rosdolsky og Reichelt som af deres lokale intellektuelle miljø, har leveret et forsøg på at fortolke revenuform-analysen som et led, der knytter kapitalanalysen sammen med statsanalysen (i Cirkular 3, Erlangen 1972). Reichelt havde allerede givet følgende programmatiske formulering:

»De (overfladeformerne, EHKR) besegler samtidig den teoretiske kapitulation overfor fordoblingsstrukturen for 'alle elementer i borgelige og statsvæsen', som det hedder i ungdomsskrifterne.« (Reichelt p. 92; da: p. 111)

MG Erlangen fors $\varnothing$ ger praktisk at udbygge det marxske fragment. Behandlingen af de »tre revenukilder « er mere end en side lang, og gengiver nogle af Marx' argumenter fra Kapitalen (Rh. 3, 1058-1064; K3, 830-834). Så følger ti sider med systematisk udvikling af kategorier så som "privat ejendom«, »valgfrihed «, »forståelse «, »almen interesse «, »konkurrence om distributionen «, »interessekoalitioner«, »klasser«, og »almen vel-være«. Dernæst følger yderligere 7 sider om »specifikke karakteristika ved revenukilden arbejde « og om borgerlige arbejderes bevidsthed (arbejdernes revenuinteresser). De sidste 4 sider er helliget forholdet mellem revenuformerne og staten. I begyndelsen af deres papir skriver MG Erlangen:

»Karl Marx når med udviklingen af 'den trinitariske formel' i slutningen af 3. bind af Kapitalen frem til overfladen af det kapitalistiske samfund, hvor 'de samfundsmæssige forholds tingsliggørelse, den umiddelbare sammenvoksen af stoflige produktionsrelationer med deres historisk-sociale bestemthed, er fuldendt'.«(p. 3, citat fra Marx: Rh3, 1068; K3, 838)

Uden at lade sig forstyrre af de svage punkter i Marx' behandling skriver de én gang til nogle få linier senere:

»kapital og jordejendom falder sammen med deres stoflige væren som produktionsmidler (og penge, der til enhver tid kan forvandles til produktionsmidler)«, som om dette udbedrede manglerne.

Flatow og Huisken ${ }^{5}$, der baserer sig på Erlangen-diskussionen, fremhæver også »revenu-niveauet « som en opsummering af Kapitalen i den »nuværen-

5. Zum Problem der Ableitung des bürgerlichen Staates, i: Prokla 7, maj 1973, 83-153. Dansk oversættelse Den borgerlige stats afledningsproblem, i: Kurasje nr. 9, p. 130-148 og nr. 10, p. 4-55. 
de diskussion om et historisk-materialistisk begreb om den borgerlige stat « (p. 83; Kurasje nr. 9, p. 131). Den egentlige revenuformanalyse er sammenfattet på to sider og uden videre bliver den aktive kapitalist identificeret med arbejderen (p. 102, 104) og indkomst bliver identificeret med revenu. »Kapital er ikke længere en samfundsmæssig relation, men kun et produceret produktionsmiddel.« (p. 105; Kurasje nr. 10, p. 8) Men hvordan kan revenukilden lånekapitals stoflige form forstås som producerede produktionsmidler? I stedet for en nærmere diskussion af den unægtelige »vanskelighed « i overgangen fra »kapital uden for produktionsprocessen « til »kapital $i$ produktionsprocessen « (p. 102; 6) følger der den lakoniske bemærkning: »Penge, der fungerer som middel til byttet med produktionsmidler, skal der ikke tages særskilt hensyn til her.« (p. 105; 8) Endnu engang forbliver svaghederne i Marx' fremstilling uberørt.

I »Oberfläche und Staat« (Berlin 1974) kritiserer Projekt Klassenanalyse (PKA) de tekster, der er skrevet af MG Erlangen og Flatow og Huisken. De giver en temmelig omfattende behandling af »overfladen« og skelner mellem niveauet for den simple varecirkulation og niveauet for revenuformanalysen. Deres »Materialien zur Klassenstruktur der BRD. Erster Teil. Grundlagen und Kritiken" (Berlin 1973) indeholder en temmelig forvirret diskussion om virksomhedsprofit (p. 36), hvor fem slags indkomster dukker op: de tre »produktionsfaktoromkostninger « (formodentlig løn, jordrente og rente) så vel som virksomhedsløn (i alle tilfælde) og virksomhedsprofit (i undtagelsestilfælde). Hermed er den trinitariske formel implicit overvundet, hvilket imidlertid ikke får PKA til at kritisere Marx' konstruktion (som de citerer p. 51) om sammenfaldet mellem revenukilderne og produktionselementerne.

Arbeitskonferenz, München (senere Marxistische Gruppe) opstiller følgende spørgsmål i det første nummer af deres tidsskrift »Resultate der Arbeiterkonferenz « (sept. 1974): »Hvorfor mislykkes marxisterne i deres fors $\emptyset \mathrm{g}$ på at forklare den borgerlige stat? «, og de kritiserer her blandt andre PKA og Flatow og Huisken. I deres kritik af Flatow og Huisken bifalder de det fremlagte udgangspunkt på »overfladen af det borgerlige samfund« (p. 150), som ydermere karakteriseres som det niveau, hvor individerne »formålsrettet og bevidst omgås med deres revenukilder (den sidste kategori i Kapitalen) og at denne omgang opviser selvstændige former, som må analyseres... Da det for dem (Flatow og Huisken, EHKR) drejer sig om staten, gennemfører de ingen analyse af konkurrencen, men begrænser sig til dennes almene former «. (ibid.) Fem år senere, da deres egen pjece om statsteori udkom ${ }^{6}$, forventede man at finde en analyse af konkurrencen som formidling af overgangen fra de »sidste kategorier i Kapitalen « (som i følge MG overhovedet ikke behøver at rekonstrueres) til staten. Sådanne forventninger blev skuffede. I det første systematiske afsnit (p. 8) finder man intet spor af revenukilderne, men i stedet en uformidlet omtale af $»$ den $\varnothing$ konomiske konkurrence med hensyn til privat

6. Marxistische Gruppe, Der bürgerliche Staat, München 1979. 
ejendom «. Den begrebsmæssige relation mellem »revenukilde « og »ejendom« lades fuldstændigt uafklaret. ${ }^{7}$

7. Sayer (Marx' Method: Ideology, Science and Critique in 'Capital', Sussex 1979) vier tredie kapitel af sin bog til en ukritisk genfortælling af Marx' analyse af arbejdskraft, profit, jordrente, rente og den trinitariske formel. Kozo Uno (Principles of Political Economy, Sussex 1980) gør stort set heller ikke andet end kort at opsummere Marx' behandling af den trinitariske formel. Uno adskiller sig fra Marx ved at kritisere tilforordningen af renten til kapitalen som dens karakteristiske revenu. I stedet udnævner han profitten til at være kapitalens revenu.

\section{nyt hos KURASJEs Bogimport}

\section{SYMPOSION BOKFÖRLAG}

Hans Peter Duerr

Drömtid - Om gränsen mellan det vilda och det civiliserade $\ldots \ldots \ldots$ kr. 123,00

Jan Thavenius

Liv och historia - Om människan i historien och historien i människan . kr. 132,00

Rudi Dutschke

Gå upprätt - En fragmentarisk självbiografi $\ldots \ldots \ldots \ldots \ldots \ldots \ldots$ kr. 111,00

Rudi Dutschke

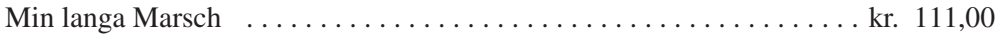

Donald Broady

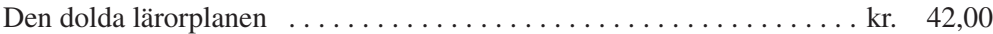

Jan Thavenius

Modersmål och fadersarv $\ldots \ldots \ldots \ldots \ldots \ldots \ldots \ldots \ldots \ldots \ldots$ kr. 111,00

Bestil bøgerne direkte hos

KURASJE, Krystalgade 16, 1172 København K.

Særrabat for abonnenter. 